\title{
O USO DE ANTIBIÓTICOS E A APRENDIZAGEM DE CONCEITOS BIOLÓGICOS EM UMA ESCOLA DA REDE PÚBLICA DE ENSINO, EM TERESINA-PI
}

\section{THE USE OF ANTIBIOTICS AND THE LEARNING OF BIOLOGICAL CONCEPTS IN A SCHOOL OF THE PUBLIC EDUCATION NETWORK IN TERESINA-PI}

\author{
Adna Dallyla Torres Lopes ${ }^{1}$; Alanderson Carlos Vieira Mata²; Emília Alexandrina dos \\ Santos Silva ${ }^{3}$; Evandro Bacelar Costa ${ }^{4}$; Francisco de Assis Diniz Sobrinho ${ }^{5}$
}

\section{INTRODUÇÃO}

O termo antibiótico refere-se ao produto metabólico de um organismo que é danoso ou inibidor para outro microrganismo, mesmo em concentrações pequenas. Existem diversos tipos de antibióticos, com diferentes modos de ação e específicos para cada tipo de bactérias. Atualmente, há um consumo abusivo de antibióticos por meio da automedicação, prescrições médicas equivocadas e até mesmo pela nossa alimentação (BERQUO, et al. 2004).

Segundo Martins et. al. (2015), os antibióticos estão perdendo sua eficácia, com o aparecimento de micro-organismo resistentes, aumentando a possibilidade de voltarmos a era pré-antibiótica, consequência do uso inadequado dos mesmos. Assim, o combate a expansão de organismos resistentes a antibióticos deve começar com a produção de conhecimentos biológicos relacionados ao assunto e o entendimento de como os antibióticos devem ser utilizados.

Visto que situações relacionadas ao uso de antibióticos estão presentes no cotidiano dos estudantes e, dentre as competências e habilidades a serem desenvolvidas em Biologia estabelecidas nos Parâmetros Curriculares Nacionais (PCN), inclui relacionar os diversos conteúdos conceituais de Biologia (lógica interna) na compreensão dos fenômenos, faz se necessário investigar o entendimento sobre a resistência bacteriana aos antibióticos, visto o atual cenário de medicação indiscriminada.

Assim, o objetivo da pesquisa foi verificar os conhecimentos sobre resistência bacteriana pelo uso inadequado de antibióticos, sua aplicabilidade, além do uso de antibióticos pelos estudantes.

Para isso, a coleta dos dados se deu por meio de questionários aplicados aos iscentes,

\footnotetext{
${ }^{1}$ Licenciatura em Ciências Biológicas, Instituto Federal do Piauí, adnadallyla123@gmail.com

${ }^{2}$ Licenciatura em Ciências Biológicas, Instituto Federal do Piauí, alandersonmata@ outlook.com

${ }^{3}$ Licenciatura em Química, Instituto Federal do Piauí, emillia-2010@ @otmail.com

${ }^{4}$ Licenciatura em Ciências Biológicas, Instituto Federal do Piauí, evandrobc1@ hotmail.com

${ }^{5}$ Professor do Departamento de Formação de Professores, Letras e Ciência/ Instituto Federal de Educação, Ciência e Tecnologia do Piauí (IFPI) - Campus Teresina Central, profdiniz@ifpi.edu.br
} 

análise dos dados e posteriormente, introdução do conteúdo de Evolução.

Diante dos resultados, o estudo contribuiu para instrução do uso correto dos antibióticos, conhecimento das possíveis dificuldades dos estudantes e direcionamento no estudo do tema, como serve de parâmetro para pesquisas na área da saúde e no ensino de Biologia em outros contextos.

\section{FUNDAMENTAÇÃO TEÓRICA}

Os antibióticos são fármacos que revolucionaram o tratamento de doenças causadas por bactérias, entretendo, seu uso inadequado acelera o processo natural de resistência das bactérias, o que resulta na perda de eficiência desses medicamentos (COSTA \& SILVA JUNIOR, 2017).

Ao ser descoberto em 1928, o antibiótico penicilina apareceu como um grande avanço da ciência e um importante arsenal terapêutico para os médicos no tratamento e cura de doenças até então incuráveis (PEREIRA; PITA, 2005). Atualmente, vivemos uma situação inversa, com o uso inadequado e consumo abusivo de antibióticos, originados principalmente da automedicação e prescrições médicas equivocadas (WECKX, 2012).

O desenvolvimento da resistência bacteriana aos antibióticos resultante da pressão seletiva exercida pelo uso dos antibióticos tem sofrido uma expansão muito acelerada e é considerada um dos problemas de saúde mais relevantes (LOUREIRO et. al., 2016).

Os conhecimentos de Biologia têm grande importância no contexto da saúde humana, para capacitação dos jovens no enfrentamento de dificuldades relacionadas à saúde humana através do conhecimento necessário que seja exigido (KORB; TEIXEIRA; RODRIGUES, 2011).

Segundo Krasilchik (2004), a formação biológica deve contribuir para que o indivíduo compreenda as explicações atualizadas de processos e conceitos biológicos.

No que se refere à resistência bacterina aos antibióticos, a questão central é que os conhecimentos de biologia, por exemplo, como os micro-organismos patógenos causam doenças, dentre outras questões, devem estar e ser evidenciados na matriz curricular de Biologia (KORB; TEIXEIRA; RODRIGUES, 2011).

\section{METODOLOGIA}

A pesquisa é caracterizada como de natureza quanti-qualitativa, possibilitando assim, uma maior margem de segurança dos resultados (DIEHL; TATIM, 2004) e do tipo descritiva, a qual busca descrever uma realidade sem nela interferir. A coleta de dados precedeu a introdução do conteúdo de evolução e deu-se através da aplicação de questionários a 135 alunos 
do $3^{\circ}$ ano do Ensino Médio de uma escola da rede pública de ensino em Teresina, Piauí.

Após a análise dos dados, foram ministradas aulas expositivas-dialogadas explicando a ação dos antibióticos na célula bacteriana, a relação entre o uso indiscriminado de antibiótico e a evolução das bactérias resistentes, com o intuito do desenvolvimento do pensamento crítico e a tomada de decisões conscientes, e assim, aliar a teoria do conteúdo de evolução à vivência dos estudantes.

\section{RESULTADOS E DISCUSSÕES}

No que diz respeito ao conhecimento biológico sobre resistência bacteriana pelo uso inadequado de antibióticos, os estudantes foram questionados incialmente sobre a classificação das bactérias e, a grande maioria $(85,18 \%)$ assinalaram procariontes e unicelulares. O estudo das características dos seres vivos e de sua morfofisiologia são conteúdo da matriz curricular de Biologia e assim, são competências dos estudantes do ensino médio (KRASILCHIK, 2004). Já quando foram questionados sobre o fenômeno que explica a resistência bacterina 90 $(66,66 \%)$ consideram que se trate da Seleção Natural, seguidos de $41(30,37 \%)$ se referindo à lei dos caracteres adquiridos.

Ainda sobre a resistência bacteriana, a maioria dos estudantes consideram o DNA da bactéria como a estrutura que promove essa resistência, como pode ser observado na figura a seguir.

Figura 1. Estrutura que promove resistência bacteriana, apontadas pelos estudantes de uma escola da rede pública de ensino, em Teresina-PI. Fonte: Própria

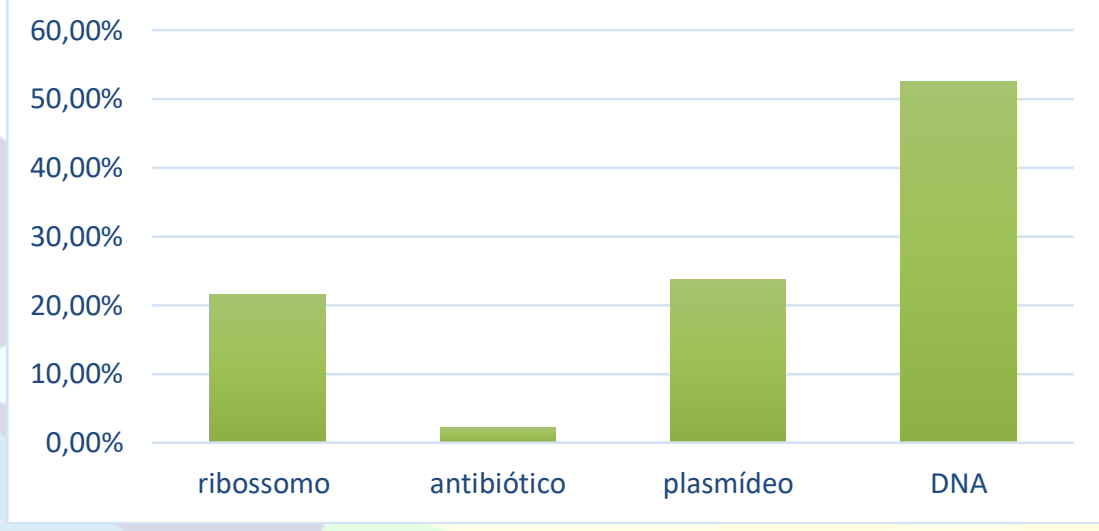

A resposta correta seria plasmídeo, porém essa dificuldade em identificá-lo como a estrutura a qual se trata é justificável devido a grande ênfase dos livros didáticos quanto ao ácido desoxirribonucleico (DNA) como estrutura responsável pelos comandos das células. No entanto, não deixa de ser uma questão a ser trabalhada.

Em outro questionamento foi solicitado para assinalarem doenças causadas por 
bactérias, 57 (42,22\%) marcaram em Tuberculose e Tétano, seguido de 42 (31,11\%) que assinalaram em Poliomielite e Sífilis, 24 (17,77\%) Tétano e Pneumonia, 12 (8,88\%) Meningite e Candidíase, o que mostra que os estudantes ainda se confundem com os agentes infecciosos das doenças, apesar de a maioria assinalar corretamente.

Quanto ao uso de antibiótico, a pesquisa mostra a prevalência maior entre as mulheres do que nos homens e um elevado índice de automedicação. Conforme Paulo \& Zanine (1988), “automedicação é um procedimento caracterizado pela iniciativa em utilizar um produto que acredita beneficia-lo no tratamento de doenças ou alívio de sintomas. "

Tanto a automedicação como a prescrição errônea, podem gerar efeitos indesejáveis, e ter como consequência o surgimento de patologias e mascaramento de doenças evolutivas, apresentando-se, portanto, como um problema a ser prevenido (ARRAIS, et al., 1997). A figura 2 mostra a prevalência do uso de antibióticos entre os entrevistados e a relação da automedicação entre homens e mulheres. Nesses dados 35 (25,92\%) dos estudantes não fizeram nenhum uso de antibióticos.

Figura 2. Prevalência do uso de antibiótico e automedicação entre homes e mulheres nos últimos seis meses, entre os estudantes da $3^{a}$ série do Ensino Médio de uma escola pública de Teresina-PI. Fonte: Própria

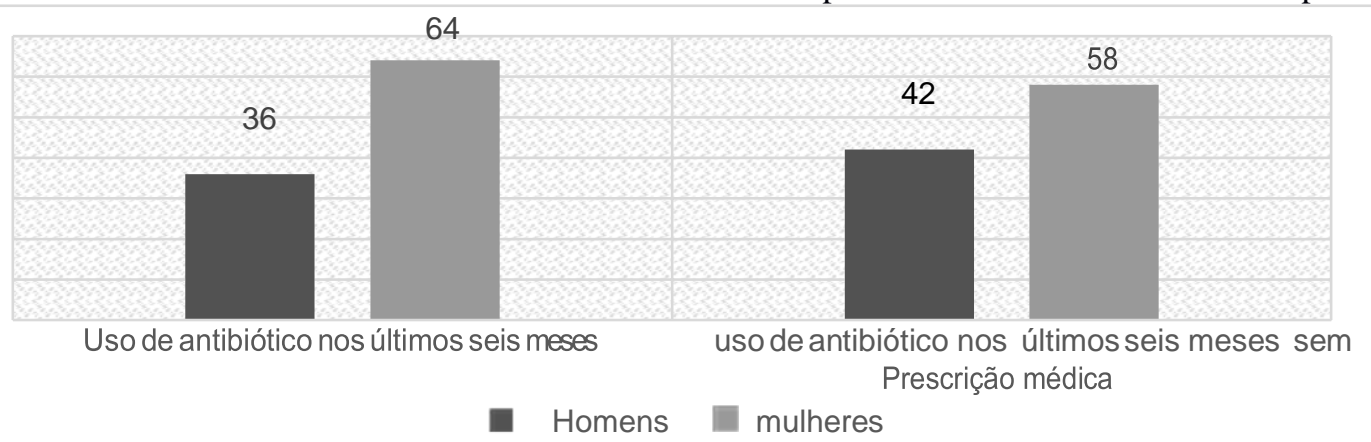

Mesmo após a resolução RDC 20/2011 da Anvisa, que condiciona a venda de antibióticos a pacientes com prescrição médica de duas vias, a maioria dos entrevistados afirma ter conseguido estes medicamentos em farmácias, sem prescrição médica, como mostra a figura 3.

Figura 3. Origem dos antibióticos usados nos últimos seis meses por estudantes da $3^{\mathrm{a}}$ série do Ensino Médio de uma escola pública de Teresina-PI. Fonte: Própria

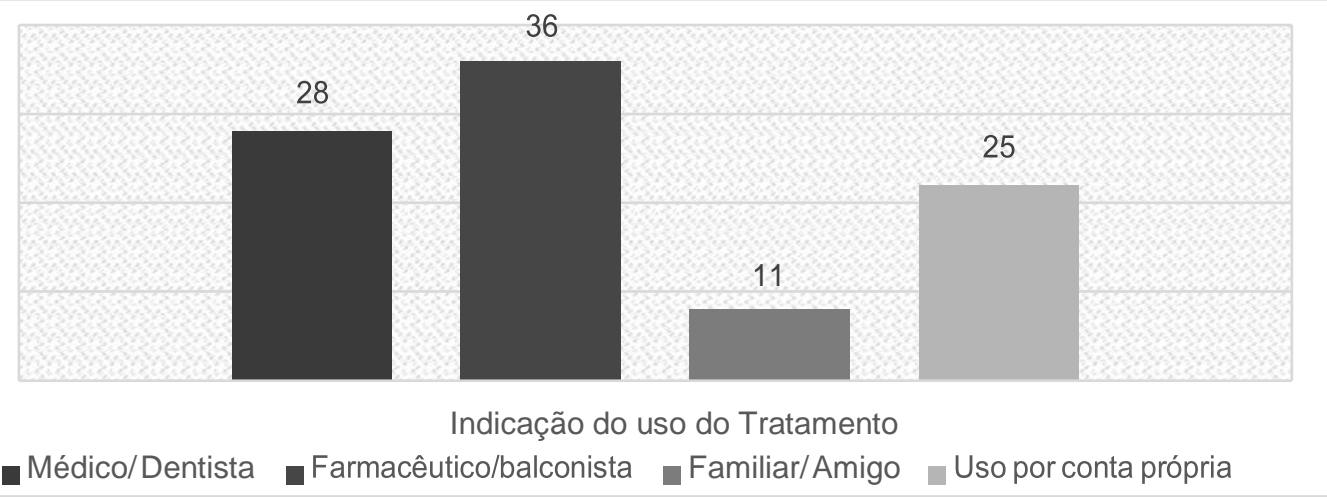


Entre os entrevistados que fizeram uso de antibióticos com prescrição médica, os dados mostram que $82 \%$ não completam o tratamento como prescrito, não tomando a medicação nos horários prescritos e até mesmo interrompendo o tratamento. A resistência das bactérias aos antibióticos acontece porque o genoma bacteriano é altamente dinâmico, embora seja curto e econômico. Bactérias sensíveis podem receber genes cromossômicos mutantes de bactérias já resistentes, através dos processos de transformação, conjugação ou transdução, com falamos anteriormente (WANNMACHER, 2004).

\section{CONCLUSÕES}

Pode-se concluir que apesar de alguns resultados positivos, temos que avançar em uma educação voltada para o pensamento crítico, com a formação de cidadãos detentores de conhecimento científico, capazes de entender situações problema no seu cotidiano.

\section{REFERÊNCIAS}

ARRAIS, P. S. D. et al. Perfil da automedicação no Brasil. Revista saúde pública, v. 31, n. 1,1997 .

BERQUÓ, L. S. et al. Utilização de antimicrobianos em uma população urbana. Revista de Saúde Pública. São Paulo, v.38, n.2, abr. 2004

COSTA, A. L. P.; SILVA JUNIOR, A. C. S. Resistência bacteriana aos antibióticos e Saúde Pública: uma breve revisão de literatura. Estação Científica (UNIFAP). Macapá, v. 7, n. 2, maio/ago. 2017.

DIEHL, A. A.; TATIM, D. C. Pesquisa em ciências sociais aplicadas: métodos e técnicas. São Paulo: Prentice Hall, 2004.

KRASILCHIK, M. Práticas de ensino de biologia. 4 ed. São Paulo: Editora da Universidade de São Paulo, 2004.

KORB, A.; TEIXEIRA, D. C.; RODRIGUES, R. M. Os conhecimentos em biologia na educação em saúde. Revista de Biologia e Ciências da Terra, Paraíba, v. 11, n. 1, 2011.

LOUREIRO, R. J. et. al. O uso de antibióticos e as resistências bacterianas: breves notas sobre a sua evolução. Revista Portuguesa de Saúde Pública. v. 34, n. 1, jan/abr. 2016.

MARTINS, G. S. et. al. Uso indiscriminado de antibióticos pela população de São José do Calçado (ES) e o perigo das superbactérias. Acta Biomedica Brasiliensia. v. 6, n. 2. 2015.

PAUlO, L.G.; ZANINE A. C. Automedicação no Brasil. Rev. Ass. Med. Bras. 34: 69-75, 1988.

PARÂMETROS CURRICULARES NACIONAIS (PCN). Brasília. Ensino Médio,1999. 
PEREIRA, A. L.; PITA, J. R. Alexander Fleming (1881-1955), Da descoberta da penicilina (1928) ao Prémio Nobel (1945). Rev. da Faculdade de Letras: História Porto, v. 6, 2005.

WANNMACHER, L. Uso indiscriminado de antibióticos e resistência microbiana: uma guerra perdida. Uso racional de medicamentos: temas selecionados, v. 1, n. 4, 2004.

WECKX, L. Antibióticos: do uso ao abuso. Braz. J. Otorhinolaryngol, São Paulo, v. 78, n. 2, abr. 2012. 